Acta Theriologica 40 (3): 295-301, 1995.

PL ISSS 0001-7051

\title{
Occurrence of lactation in red deer Cervus elaphus
}

\author{
Ryszard DZIĘCIOŁOWSKI, Michał WASILEWSKI, \\ Jacek GOSZCZYŃSKI and Joanna BABIŃSKA-WERKA
}

\begin{abstract}
Dzięciołowski R., Wasilewski M., Goszczyński J. and Babińska-Werka J. 1995. Occurrence of lactation in red deer Cervus elaphus. Acta Theriologica 40: 295-301.

Lactation was studied in red deer Cervus elaphus Linnaeus, 1758 hinds from the Słowiński National Park during years 1990-1994. Yearling hinds did not participate in breeding. It was only 2.5 years old and older hinds that lactated. Lactation was prolonged until December and January when 52\% of hinds were still lactating. Physical condition of hinds as measured with body weight, KFI, and visceral fat content did not differ significantly between lactating and not lactating hinds. The proportion of lactating hinds was declining until 1993 and increased in 1994. This was accompanied by a drop in the index of recruitment, ie the number of calves per 100 hinds.
\end{abstract}

Department of Forest Zoology and Wildlife Management, Agricultural University, 02 -528 Warsaw, Rakowiecka 26/30, Poland

Key words: Cervus elaphus, lactation, occurrence, duration, dependence on condition

\section{Introduction}

The period of lactation is of crucial importance to hinds. Lactation is associated with a rapid decline in the mother's body reserves, and a hind that invests too heavily during this period not only may be less likely to conceive the following autumn but may also enter the winter in poor condition, risking both her own life and that of her calf (Clutton-Brock et al. 1982).

Lactation in red deer hinds provides a very useful index of recruitment. The number of lactating hinds in autumnal and winter population equals the number of calves in it. In Poland, the mean recruitment index is close to 65 calves/100 hinds (Bobek et al. 1992). It is comparable to the Scottish data showing from 40 calves per 100 hinds in the hill range to 70 in good habitats of Grizedale (Mitchell et al. 1981).

The purpose of our studies was to examine the proportion of lactating hinds and their condition in the Słowiński National Park. Red deer population density was high there and amounted to ca 100 individuals per 1000 ha of forest area (Dzięciołowski et al. 1995). 


\section{Study area}

Studies were carried out in the Słowiński National Park $\left(54^{\circ} 33^{\prime} \mathrm{N}, 17^{\circ} 46^{\prime} \mathrm{E}\right)$ situated on the Baltic Sea coast. The area of park covers 18247 ha, out of which lakes constitute more than a half (9763 ha). Physiographic diversity is considerable. Forest tracts, meadows, dunes and reeds surrounding lakes are the most important habitats for the local red deer population. The landscape of Słowiński National Park constitutes an interesting mosaics of the ecosystems mentioned.

Scots pine Pinus silvestris is the most important forest-forming tree species. Coastal pine forest (Empetro nigri-Pinetum) is a dominant forest association on the Łeba Bar. Deciduous forests play a minor role. They are represented by mesophilous relict beechwood, alderwood (Carici elongatae-Alnetum) adjoining lakes, poor alluvial woodland (Circaeo-Alnetum) and willow shrubs (MyricoSalicetum).

During winter the deer gather first of all in forests and on dunes. Reeds, shrubs adjoining lakes, and bogs are during this season by far less attractive due to the raised water level and scanty food resources. Apart from food gained in diurnal mainstays, red deer feed on the adjoining meadows, pastures, and cultivated fields.

\section{Methods}

Three hundred and eight hinds have been harvested in the course of red deer culling carried out in 1990-1994 in the Słowiński National Park. The presence of milk in udders was assessed for all hinds. Age of 308 females was appraised according to annual rings in the first molar (modified techniques of Mitchell 1967). Condition of hinds was also examined with the aid of the three parametres, namely body weight, Kidney Fat Index (KFI), and the amount of visceral fat. Body weights were measured to the nearest $0.5 \mathrm{~kg}$ for a cleaned (eviscerated) carcass with head and legs. KFI was the mass of kidney with fat in $g$ divided by the mass of kidney without fat in $g$. Amount of visceral fat had been appraised subjectively by technician and assigned to one of the following categories: lack of fat, slight amount of fat, and abundant fat.

Recruitment was assessed with the aid of two methods. The first one consisted in the calculation of the proportion of all hinds lactating in a given year in relation to all hinds harvested including yearlings. The other one was based on direct field observations of 1689 hinds and calves from July to September. One- and two-factor ANOVA, test for comparing two per cents, and $\chi^{2}$-test for goodness of fit were used for statistical analysis of data.

\section{Results}

No lactation was found in 1.5 years old hinds during five years of studies. Older females participated in breeding what was evidenced by the presence of milk in their udders (Table 1). Within the group of 2.5 years old hinds the proportion of lactating ones was significantly lower than in older age classes $\left(\chi^{2}=22.74, p<\right.$ 0.001 ). Among older hinds the proportion of lactating ones varied within limits from 68 to $88 \%$ (Table 1 ), but this variation was statistically insignificant $\left(\chi^{2}=\right.$ $3.98, p>0.05$ ). In this connection for further analyses hinds were divided into two groups: young (2.5 years old) and adult (3.5 years old and older).

Proportion of hinds lactating during successive months revealed statistically significant differences between months $\left(\chi^{2}=8.61, p<0.05\right)$. It varied from $72 \%$ 
in September to 52 in December and January (Table 2). This is an evidence of a prolonged duration of lactation persisting well into winter months.

In order to find whether only females in good condition participate in successful breeding, indices of condition were compared for lactating versus non-lactating hinds (Table 3). Among adult hinds the number of these with abundant visceral fat was higher in lactating (circa 70\%) than non-lactating (ca 52\%) ones (Table 3; test for comparing two per cents: $d=2.33, p<0.05$ ). A reversed relationship occurs in the group of 2.5 years old hinds ( $d=1.20, p>0.05$ ).

The mean body weight did not differ statistically between lactating $(72.2 \mathrm{~kg})$ and non-lactating hinds $(69.9 \mathrm{~kg})$ (ANOVA: $F=0.44, p=0.51$ ). On the other hand 2.5 years old differed significantly in body weight from older hinds both in the group of lactating and in nonlactating ones $(F=17.37, p<0.0001)$. Young females were simply lighter than older ones both among lactating and non-lactating ones (Table 3).
Table 1. Proportion of lactating hinds in individual age-classes.

\begin{tabular}{ccc}
\hline $\begin{array}{c}\text { Age-class } \\
\text { (yrs) }\end{array}$ & $\begin{array}{c}\text { Number of } \\
\text { hinds }\end{array}$ & $\begin{array}{c}\text { Percent } \\
\text { lactating }\end{array}$ \\
\hline 1.5 & 48 & 0 \\
2.5 & 48 & 39.6 \\
3.5 & 40 & 77.5 \\
4.5 & 30 & 76.7 \\
5.5 & 31 & 71.0 \\
6.5 & 24 & 87.5 \\
7.5 & 14 & 71.4 \\
8.5 & 23 & 78.3 \\
$\geq 9.5$ & 50 & 68.0 \\
\hline
\end{tabular}

Table 2. Proportion of lactating hinds during successive months ( $\geq 2.5$ years old hinds).

\begin{tabular}{lcc}
\hline Months & $\begin{array}{c}\text { Number of } \\
\text { hinds }\end{array}$ & $\begin{array}{c}\text { Percent } \\
\text { lactating }\end{array}$ \\
\hline September & 107 & 71.7 \\
October & 63 & 76.2 \\
November & 40 & 70.0 \\
December and & 50 & 52.0 \\
January & & \\
\hline
\end{tabular}

Table 3. Condition of lactating vs non-lactating young and adult hinds.

\begin{tabular}{|c|c|c|c|c|c|c|c|c|c|}
\hline \multirow[b]{2}{*}{ Hinds } & \multirow[b]{2}{*}{ Age-class } & \multicolumn{3}{|c|}{ Body weight (kg) } & \multicolumn{3}{|c|}{ Kidney Fat Index } & \multicolumn{2}{|r|}{ Visceral fat } \\
\hline & & $n$ & Mean & $\mathrm{SE}$ & $n$ & Mean & $\mathrm{SE}$ & $n$ & $\begin{array}{c}\% \text { of hinds } \\
\text { with abundant } \\
\text { visceral fat }\end{array}$ \\
\hline \multirow[t]{3}{*}{ Lactating } & 2.5 & 19 & 66.4 & 1.66 & 15 & 1.65 & 0.11 & 19 & 63.2 \\
\hline & $\geq 3.5$ & 159 & 72.9 & 0.70 & 142 & 1.63 & 0.03 & 159 & 69.8 \\
\hline & Mean & 178 & 72.2 & 0.66 & 157 & 1.64 & 0.03 & - & - \\
\hline \multirow[t]{3}{*}{ Non-lactating } & 2.5 & 29 & 66.3 & 1.57 & 24 & 1.90 & 0.10 & 29 & 79.3 \\
\hline & $\geq 3.5$ & 53 & 71.9 & 1.19 & 51 & 1.68 & 0.10 & 54 & 51.8 \\
\hline & Mean & 82 & 69.9 & 0.99 & 75 & 1.75 & 0.07 & - & - \\
\hline
\end{tabular}


Table 4. Condition of lactating hinds ( $\geq 2.5$ years old) during successive years, 1990-1994.

\begin{tabular}{|c|c|c|c|c|c|c|c|c|}
\hline \multirow{2}{*}{ Years } & \multicolumn{3}{|c|}{ Body wt (kg) } & \multicolumn{3}{|c|}{ Kidney Fat Index } & \multicolumn{2}{|c|}{ Percent of fat individuals } \\
\hline & $n$ & Mean & SE & $n$ & Mean & $\mathrm{SE}$ & $n$ & Mean \\
\hline 1990 & 61 & 74.7 & 1.25 & 56 & 1.73 & 0.05 & 61 & 78.7 \\
\hline 1991 & 29 & 69.8 & 1.77 & 20 & 1.74 & 0.09 & 29 & 55.2 \\
\hline 1992 & 20 & 71.4 & 2.03 & 20 & 1.83 & 0.11 & 20 & 75.0 \\
\hline 1993 & 9 & 73.8 & 1.88 & 9 & 1.48 & 0.11 & 9 & 22.2 \\
\hline 1994 & 59 & 70.7 & 0.95 & 52 & 1.45 & 0.04 & 59 & 71.2 \\
\hline
\end{tabular}

KFI analysis did not indicate significant relationship between age and condition in lactating and non-lactating hinds $(F=2.04, p=0.154$; Table 3$)$. No differences in KFI values were found between lactating versus non-lactating hinds $(F=2.68$, $p=0.103$ ). Similarly no differences were found in the percentage of hinds with abundant fat reserves between the two groups (test for the comparison of two per cents: $\mathrm{d}=1.21, p>0.05$ ).

Body weight of lactating hinds was maintained on an uniform level during the studies $(F=2.36, p>0.05)$, while KFI values and per cent of hinds with abundant fat reserves varied significantly during successive years $(F=6.00, p=0.0002$; $\mathrm{d}=3.25, p>0.01$ for 1993 and 1994; Table 4). There was noted some convergence between the per cent of hinds with abundant fat reserves and that of lactating hinds during successive years, but this correlation was statistically insignificant $(r=0.81, p>0.05)$.

Table 5. Proportion of lactating hinds ( $\geq 2.5$ years old) during successive years.

\begin{tabular}{lllllll}
\hline Year & 1990 & 1991 & 1992 & 1993 & 1994 & Total \\
\hline$n$ & 75 & 42 & 35 & 23 & 85 & 260 \\
Percent lactating & 81.3 & 69.1 & 57.1 & 39.1 & 68.2 & 68.1 \\
\hline
\end{tabular}

Table 6. Comparison of two estimates of recruitment as expressed by number of calves/100 lactating hinds harvested and number of calves/100 hinds observed in the field.

\begin{tabular}{lcccccc}
\hline Recruitment & 1990 & 1991 & 1992 & 1993 & 1994 & Mean \\
\hline $\begin{array}{l}\text { Number of calves/100 hinds } \\
\text { (according to the proportion of lactating } \\
\text { hinds among those harvested) }\end{array}$ & 69 & 62 & 44 & 33 & 63 & 59 \\
& $(118)$ & $(65)$ & $(45)$ & $(27)$ & $(101)$ & $(356)$ \\
$\begin{array}{l}\text { Number of calves/100 hinds } \\
\text { (observed in the field) }\end{array}$ & 61 & 44 & 33 & 62 & 41 & 44 \\
& $(305)$ & $(529)$ & $(44)$ & $(99)$ & $(315)$ & $(1689)$ \\
\hline
\end{tabular}


Proportion of lactating hinds was diminishing in the course of the four successive years of studies and amounted to $81,69,57$, and $39 \%$ respectively, but increased to $68 \%$ in the fifth year (Table 5). These differences were statistically significant $\left(\chi^{2}=17.04, p<0.01\right.$; Table 5). Assessment of recruitment based on field obsevations of hinds with calves and on proportion of lactating hinds in all years gave similar results except 1993 (Table 6).

\section{Discussion}

Results of our studies in the Słowiński National Park reveal that hinds begin to participate in breeding when 1.5 years old and calve when 2 years old. Red deer in excellent habitat conditions of New Zealand are capable of becoming fertile while still calves (Daniel 1963). Presence of embryos in yearling hinds proves that under conditions of abundant food in indigenous Nothofagus and podocarp forests, red deer hinds have their first oestrus and are successfully served as yearlings of about 16 months and calve at about 24 months of age. The incidence of yearling pregnancies may well reach $80 \%$. Similarly, in the former Yugoslavia, Valentincic (1960) found in a sample of yearling hinds from mixed oak and beech forests in the lowlands that about 30\% were pregnant, compared with none from the nutritionally poorer Alpine region of Scots pine, beech and mountain pastures. In the Scottish Highlands red deer hinds calve for the first time at 4 years and under favourable conditions may calve at 3 years of age (Mitchell et al. 1981). On the Island of Rhum the majority of hinds do not breed until they are 3 years of age, thus calving at the age of 4 years (Clutton-Brock et al. 1982). In Scotland and England it is rare for a hind to be served in her second year.

The great geographical variation in fertility rates among yearling hinds was described by Gill (1990). It appears that in Europe it varies from 0 to 0.95 .

The comparison of lactation in relation to age of hinds revealed a slightly higher productivity of the lowland population from Poland when compared to the mountain one from Switzerland (Table 7).

Lactation is prolonged in hinds, in our study until December and January. At that time the proportion of lactating hinds amounted to ca $60 \%$. Our results corroborate those of Mitchell et al. (1981) who found that $40 \%$ of hinds had been lactating in January, while 20\% in February. Arman et al. (1974) also found that lactation continues for 190 to over 280 days. Weaning,

Table 7. Comparison of lactation rates in red deer hinds between Switzerland (Buchli 1979) and Poland (this study).

\begin{tabular}{lcc}
\hline $\begin{array}{l}\text { Age-class } \\
\text { (yrs) }\end{array}$ & \multicolumn{2}{c}{ \% of lactating hinds } \\
\cline { 2 - 3 } & Switzerland & Poland \\
\hline 0.5 & 0 & 0 \\
1.5 & 0 & 0 \\
2.5 & 6.5 & 39.6 \\
3.5 & 55.3 & 77.5 \\
$4.5-6.5$ & 64.5 & 77.6 \\
$7.5-9.5$ & 70.0 & 70.2 \\
$10.5-12.5$ & 81.5 & 63.2 \\
$\geq 13$ & 56.3 & 81.0 \\
$n$ & 508 & 399 \\
\hline
\end{tabular}


according to them, is completed between December and March. On the other hand, according to Jaczewski (1989) lactation lasts from birth in May till the rut in October or till November.

According to Clutton-Brock et al. (1982) the timing of weaning differs between the offspring of mothers that become pregnant in October following the calf's birth (pregnant mothers) and those of mothers that did not (barren mothers). Pregnant mothers often wean their calves by the time they are five to seven months old the last dates on which their calves were observed to suck typically fell before the end of November. In contrast, barren mothers usually did not wean their calves till the following summer or autumn. This may explain our results evidencing lactation during winter and possibly longer. Krzywiński et al. (1980) found also that unfertilized hinds may lactate even during ca 18 months.

Costs of milk production burden the energetic budget of lactating females and cause that the condition of hinds non-participating in breeding is higher than that of lactating ones (Mitchel et al. 1981). It was only the visceral fat that indicated significantly inferior condition of lactating hinds and it was only for 2.5 years old hinds. Proportion of lactating hinds was variable in successive years of studies and declining. Condition indices analyzed by us did not confirm the relationship between lactation and condition in hinds.

The size of recruitment differed during successive years of study and amounted to $0.69,0.62,0.44,0.33$ and 0.63 calf per female (as estimated on the basis of the proportion of lactating hinds) and to $0.61,0.44,0.33,0.62$ and 0.41 (appraised from direct observations; Table 6). We guess that one of reasons for the decline in the proportion of lactating hinds in the population and consequently that of recruitment during first three years could be the decrease in amount and deterioration of quality of food resources in the environment studied. This could be a result of the abandonment of cultivation, cutting and fertilization on a vast area of meadows intensively utilized by the local red deer population from spring until autumn.

Acknowledgements: The project was jointly sponsored by two grants, namely: No 50130921 from the Polish Committee of Scientific Research and No PL-FS-97 from the Forest Service USDA.

\section{References}

Arman P., Kay R. N. B., Goodall E. D. and Sharman G. A. M. 1974. The composition and yield of milk from captive red deer (Cervus elaphus L.). Journal of Reproductive Fertility 37: 67-84.

Bobek B., Morow K., Perzanowski K. and Kosobucka M. 1992. [The red deer (Cervus elaphus) - its ecology and management]. Wydawnictwo Świat, Warszawa: 1-220. [In Polish]

Buchli C. 1979. Zur Populationsdynamik, Kondition und Konstitution des Rothirsches (Cervus elaphus L.) im und um den Schweizerischen Nationalpark. Habilitierung Dissertation, St. Gallen, Zurich: 1-99.

Clutton-Brock T. H., Guinness F. E. and Albon S. D. 1982. Red deer. Behavior and ecology of two sexes. Edinburgh University Press, Edinburgh: 1-378. 
Daniel M. J. 1963. Early fertility of red deer hinds in New Zealand. Nature 200 (4904): 380.

Dzięciołowski R., Goszczyński J., Wasilewski M. and Babińska-Werka J. 1995. Numbers of red deer in the Słowiński National Park, Poland. Acta Theriologica 40: 45-51.

Gill R. 1990. Monitoring the status of European and North American cervids. The Global Environment Monitoring System. GEMS information series, 8, Nairobi: 1-277.

Jaczewski Z. 1989. Reproduction in the red deer female and the effect of oestrogens on the antler cycle and behaviour. Acta Physiolgica Polonica 40: 85-95.

Krzywiński A., Krzywińska K., Kisza J., Roskosz A. and Kruk A. 1980. Milk composition, lactation and the artificial rearing of red deer. Acta Theriologica 25: 341-347.

Mitchell B. 1967. Growth layers in dental cement for determining the age of red deer (Cervus elaphus L.). Journal of Animal Ecology 36: 279-293.

Mitchell B., Grant W. and Cubby J. 1981. Notes on the performance of red deer, Cervus elaphus, in a woodland habitat. Journal of Zoology, London 194: 279-284.

Valentinicic S. 1960. Komparative Studie einiger Reproduktionserscheinungen beim Rotwild des Alpen. Transactions of the 4th Congress of International Union of Game Biologists, Arnhem, The Netherlands: 188-197.

Received 1 June 1994, revised 6 July 1995, accepted 11 July 1995. 